\title{
Turning Ideologies Inside Out: Developing Young Readers' Empathy for Critical Voices in Narrative Fiction
}

\author{
Íris Susana Pires Pereira ${ }^{\mathrm{a} *}$ and Ângela Campos ${ }^{\mathrm{b}}$ \\ ${ }^{a}$ Institute of Education, University of Minho, Braga, Portugal; ${ }^{b}$ Agrupamento de Escolas de \\ Ermesinde, Ermesinde, Portugal
}

\begin{abstract}
This article is located at the crossroads between two distinctive human traits, empathy and rational thought, with narrative emerging as a particularly powerful means to enable young readers to bring them together. Specifically, we discuss the role that critical literary exegesis plays in the development of empathic consciousness in literary readers. The discussion is conducted through the critical narrative discourse analysis of a short story that is widely read by Portuguese young students. The story deals with what has become a living experience for many students - emigration - and puts opposing social ideologies about this experience in a subtle dialogue. Narratological critical analysis provides an essential tool for readers to turn those ideologies inside out. It enables them to escape the main character's conformist positioning and develop a liberating empathy, and hence a more sensitive perspective about the social reality that the narrator offers for our consideration.
\end{abstract}

Keywords: literature; empathy; critical narrative discourse analysis; ideology; point of view

\section{Literature, humanity and empathy}

This essay is sustained by two major assumptions about teaching the reading of literature. One concerns the power of literary texts to enhance readers' humanity, the other, that guiding students to experience the reading of literature so as to develop empathy, a central emotional dimension of readers' humanity, is a very demanding intellectual endeavour.

Empathy is the capacity we have to grasp the minds of other people as if they were our own. It implies a 'deep emotional sharing' of others' feelings, a 'cognitive assessment of the other's present condition' and 'an affective and engaged response to attend to their needs and help ameliorate their suffering' (Rifkin 2009, 13). Empathy, understood as feeling, comprehending and doing, is nurtured by our social relationships, by parenting and by exposure to others, as well as by reflection on experience (Rifkin 2009). In turn, by being empathic, we learn that the empathic engagement 'itself also loops back to reinforce and deepen one's own sense of selfhood' (41). As Rifkin puts it, ultimately '[e]mpathy is the very means by which we create social life and advance civilization' (10).

By offering the lives of others for our contemplation, literature is a prominent cultural realm for the construction of mature empathic individuals (Volpi 2011). Indeed, Mar et al. (2006), Mar and Oatley (2008) and Mar, Oatley, and Peterson

*Corresponding author. Email: iris@ie.uminho.pt 
(2009) provide evidence for the association between reading narrative fiction and the development of empathic skills (including active social support), assuming that reading fiction involves the mental anticipation of social life. In fact, these researchers suggest that fiction's function is to aid in the simulation and abstraction of social experience. As Oatley puts it, fiction is simulation

in the sense that researchers on theory of mind such as Harris (1990) talk about it. In ordinary life, we use aspects of our understanding of ourselves to infer what others might be thinking and feeling. In fiction, authors offer us cues to our theory-of-mind processes, so that we can use these same simulative faculties for fictional characters. (Oatley 2008, 1030)

Kidd and Castano (2013) have recently interpreted similar findings about the impact of the reading of literary fiction on the development of empathic skills by assuming that 'by prompting readers to take an active writerly role to form representations of characters' subjective states, literary fiction forces us to engage in mind-reading and character construction' (377) as it 'involves identifying and interpreting the subjective experience of others' (380).

Researchers therefore tend to agree that the cultural practice of reading literature enhances such human interpersonal disposition. Although this approach to literature reading sounds very appealing to educators, we believe that it requires careful consideration. Readers' heterogeneous identities (Gee 2001) are reported to mediate other emotional responses to texts than empathy, such as anger or repulsion, actually leading students to challenge empathic positionings themselves (Wohlwend and Lewis 2010; Lewis and Tierney 2011). In this article, we focus on yet another dimension that mediates emotions in literary meaning-making, namely the literary mode of representation itself.

The literary meaning-making process is multilayered. As Pace (2006) puts it, besides feeling, it involves thinking and critical responses, which we believe may also shape empathic responses. Indeed, our aim is to contribute to the understanding of the complexity of the process of empathy development through literary reading by showing the need to support it with literary knowledge that is intended to promote critical responses to texts. Although readers may be naturally empathic to the lives they observe in literary representations, our main claim is that they may be deceived by ideological forces that merge in literary discourses. We thus focus on the ideological dimension of literary texts to argue that 'critical literary discourse exegesis', that is, a thoughtful interpretation readers construct out of a text through critical literary discourse analysis, can play an important role in the development of empathic consciousness in literary readers.

Our discussion is sustained by the critical narrative exegesis of a short story widely read by Portuguese young students. The text deals with what has become a living experience for them - emigration - and puts opposing social ideologies about such reality in a subtle dialogue. As a result, two contrasting emotional positionings are offered to readers. We show how narratological critical analysis provides an essential tool for readers to turn those ideologies inside out. It enables them to escape empathy with the main character's conformist positioning and develop a liberating, empathic perspective about the social reality that the narrator offers for readers' consideration. We thus defend the idea that critical readings may support emotional (and, thus, social) outcomes for readers of literature. We discuss some implications of our analytical stance on the learning of reading of literary texts. 


\section{Ideology in literature for children and young readers}

Ideology is the set of cultural models, naturalised and internalised by society, which conditions individuals' envisioning of their world, their meaning-making abilities and social positioning (Gee 1996; McLaren 2003). Texts are privileged spaces of dissemination of social ideologies (Gee 1996; Luke, O'Brien, and Comber 2001; Freire and Macedo 2003; Pereira 2009). Ideology is actually a multiple concept. We believe that the concepts of assimilation ideology and liberation ideology (Yoon, Simpson, and Haag 2010) illustrate the complexity of the process of ideological inscription in texts.

Assimilation ideologies are found in textual representations of dominant social rituals, habits, beliefs and values. By creating such representation, texts are compliant with such ideas, frequently producing in individuals biased conceptions about their socio-cultural place, disguising unequal power and social relations as natural states of affairs. In fact, the acceptance of assimilation ideologies is the passport to 'belong' to dominant society. On the other hand, liberation ideologies are found in texts that actively denounce unequal power and social relations, openly offering readers otherwise unperceived social realities. Such representations are resistant to hegemonic ideologies. Whereas by reading the former category of text, readers are guided to empathise with socially integrated people and to go on acting for the sake of assimilation ideologies, by reading the latter kind of text readers are guided to empathise with the lives of the socially disadvantaged people and to act on behalf of their interests. The ability to see and resist conforming ideologies and learn liberating meanings has become a key competence for the understanding and enactment of twenty-first-century citizenship (Kubow, Grossman, and Ninomiya 1998) and a central assumption in 'changing pedagogies for changing times', conceived as necessary to 'engage students in the interpretation, analysis, critique and production of signs in and for particular contexts, audiences and purposes' (Lewis and Tierney 2011, 320).

Attention has increasingly been given to children's literature, particularly narrative fiction, as a powerful means of assimilation ideology transmission (Hollindale 1988). Yet, more and more literature for children and adolescents has been written in which liberation ideologies are inscribed, denouncing and opposing assimilation ideologies (Stephens 1992; Comber 2001; Alsup 2003). Readers may therefore be positioned by whatever social ideology is inscribed in literary texts. By explicitly introducing an awareness of ideology into literary education, teachers aim to help readers to develop sociocultural understandings of texts and thus to go beyond personal and literary meaning-making into the unveiling of and resisting the ideological meanings that are inscribed in texts (Luke, O'Brien, and Comber 2001). We argue that the critical experience of literature is an essential dimension of readers' human construction due to its potential for enhancing empathy for critical stances. We are referring here to practices that move beyond literary analysis per se into social semiotics, that is, into socially relevant meaning-making practices that support meaningful identity (re)construction, both emotional and intellectual (Lewis and Tierney 2011).

\section{A methodology for critically reading narrative fiction at school}

Critical discourse analysis has gained prominence in the ideological scrutiny of texts (Dijk 1998, 2001; Fairclough 1989; Gee 2001). Norman Fairclough's (1989) work has been particularly influential in the understanding of how discursive conventions verbally construct and naturalise diverse ideological meanings, which become common sense, thus contributing to the maintenance of power relations. 
John Stephens's (1992) methodology is the most important development of Fairclough's ideas for the critical reading of narrative fiction for children and young readers. His methodology aims at helping readers actually see the processes of ideological inscription in literary texts and develop a critical attitude to the effects of such representations upon their social positioning. Stephens's narrative discourse analysis is original in the way in which he relates explicit literary and sociocultural understandings of texts to narrative exegesis. It focuses on three aspects of narrative construction, namely story, discourse and significance.

Story corresponds to what is narrated, 'what certain characters do in a certain place at a certain time' (Stephens 1992, 17). It is recognised by what Stephens calls 'primary reading (reading for "the sense")' (12), which is a reading level that allows a wide consensus made possible by shared human experience. Discourse, in turn, refers to the narrating, the complex encoding process of the story elements, such as the organisation of different narrative moments, the relation of the story elements to each other, the narrative closure, intertextuality and the narrative point of view. The narrative point of view is both the hallmark of narrative fiction for children and the most powerful element of narrative discourse. Point of view, in its 'perceptual' (who sees?) and 'conceptual' (who perceives or values?) dimensions (27), is thus assumed to be significantly responsible for the reader's subject positioning.

Stephens argues that young readers usually identify with the narrative's main character, as they are subtly and uncritically led by his or her point of view. Yet his methodology offers itself as an instrument for readers to distance themselves from such a point of view by acknowledging its existence and by allowing the identification of other points of view, such as the narrator's or another character's, as well as to negotiate the meanings they convey in order to assume a more conscious subject positioning and be allowed different emotional answers.

For Stephens, it is the analysis of the story together with that of the discursive encodement that allows the reader to deduce a significance, a 'secondary reading' (12), which is never devoid of an ideological connotation. Significance is therefore the main scope of readers' attention if they are to recognise the presence of ideology in fictional narratives, which otherwise will remain invisible, and to take a stand towards the meanings that are being constructed for them. Stephens is, however, clear about the assumption that ideology is also inscribed in the story itself, since narrative sequences and the relationship between characters are represented according to recognisable forms, which may express common or otherwise alternative assumptions about forms of human existence.

\section{Critical discourse literary analysis: an illustrative case}

'Rice from Heaven' ([1962] 1990), written by José Rodrigues Miguéis (19011980), has been part of the Portuguese educational literary canon for many years, although it was not written for young readers. It was first published at a time of political and ideological censorship in Portugal, a political circumstance that conditioned the discursive representation of social criticism as well as its reception. It appeals now, as it did then, to the capacity of reading beyond the veil of socially and politically censored meanings. Indeed, the fact that 'Rice from Heaven' is about 'emigration' reminds us of Dijk's (1998) analysis of the social polarisation between us (the dominant group) and them (the minority) as the realm for the inscription of assimilatory ideologies. Our inquiry was therefore motivated by the assumption that 
'Rice from Heaven' offers itself as a potentially generative text for developing a critical discourse analysis. We hypothesised that Stephens' methodology would allow us to scrutinise how the text conditions the ideological positioning of its readers, and, thus, their emphatic responses, which would ultimately allow us to interpret the short story's potential for developing readers' empathic consciousness.

We categorised the text's meaning units according to the categories defined in Stephen's analytical methodology (Campos 2012). In this article, we present and discuss the analysis of some such elements, namely the story; the discursive element of point of view; and the significance we deduced. In the analysis, we identified speech features involved in the construction of point of view, such as syntactic structures, figures of speech, vocabulary and verbal tenses, which we interpreted according to the meaning constructed, their effects upon the construction of point of view and readers' social positioning (Fairclough 1989; Stephens 1992; Dijk 1998).

We have also come across another relevant discursive feature to understand the semiotic construction of point of view in this narrative, namely free indirect speech, which is not explicitly referred to in Stephens's methodology, although it is central to Bakhtin's notion of dialogism (Bakhtin $(1981,1984)$. Dialogism is 'the implicit or explicit dialogue of differently situated voices that is both generated by and is the condition of all discourse' (Harris 1990, 445). Bakhtinian 'polyphony' and 'double voicing' are two central dialogical techniques we recognised through our analysis. They are used to present readers with a "plurality of consciousnesses, with equal rights and each with its own world' (Bakhtin 1984, 7, as quoted in Harris 1990, 447). Double voicing, understood as 'an encounter, within the arena of a single utterance, between two different linguistic consciousnesses' (Bakhtin 1981, 358, as quoted in Harris 1990, 453) through the use of free indirect speech, is a significant discursive feature in the construction of point of view in Miguéis's narrative.

\section{'Rice from Heaven': two ideologies in dialogue}

The analysis of the narrative illustrates the co-presence of two opposing signifcances in the story, each voicing assimilation and liberation ideologies, the former being more strongly represented than the latter: it prevails at the story level and it is also conveyed by the conformist main character's point of view. Liberation ideology is inscribed in the caustic, yet less powerful, narrator's perspective.

'Rice from Heaven' is about an immigrant from an Eastern European country living in New York. He worked in the 'subway' (Miguéis [1962] 1990, 68), ${ }^{1}$ the city's underground, as pathway-cleaner. Action takes place mainly in such 'dark' and 'dirty' (68) places where the worker routinely did his job. One day he found a few 'grains of rice on the floor' (70) and, after noticing that this event repeated and that the rice accumulated, he started gathering it and taking it home to feed himself and his large family. As the poor immigrant did not know the upper side of the city, the 'Uptown' (69), nor was he familiar with the cultural ritual of throwing rice at weddings that took place regularly on the street above, he attributed the phenomenon to the divine 'Providence' (71).

The main character's psychological features, 'so poor and quiet' (71), 'always with his eyes on the floor' (68), 'awkward and silent' (68), 'always alone' (70) are in accordance with his 'resigned' (68) attitude, i.e. with his passive acceptance of his social condition and attitudes contrary to self-emancipation and personal and professional improvement. The pathway-cleaner's passivity led him to his final 
conversion to religion, based on his misunderstanding, being grateful for being the object of God's will, although remaining poor and ignorant.

The glimpses we get from the 'Uptown' strongly contrast to such passivity: agentive and energetic children play, moving easily from the 'Uptown' to the 'subway', suggesting other happier lives beyond the pathway-cleaner's story.

Concerning the inscription of ideology at the story level, we can say that a 'primary reading' of this narrative potentially mobilises 'assimilation' ideological assumptions about society and social forms of labour organisation, identifying characters as belonging to distinct social groups: the poorest and least educated, especially immigrants, living in 'lower' places, where less desirable and poorly rewarded tasks are performed, and the socially and economically privileged groups belonging to 'higher' social places (Dijk 1998), the former resigned to their condition, the latter indifferent to the other's social exclusion.

\section{The discourse: seeing opposing ideologies}

The 'primary reading' effects mentioned before are potentially deconstructed as we emerge into discourse analysis ('secondary reading'). We found that the coexistence of character's and narrator's point of view - each one immersed in opposing ideologies - is a complex process of ideological inscription and potential reader's positionings.

It is through the main character's eyes that in the third, seventh, eighth, ninth and tenth paragraphs the narrative flows, the reader being offered the pathway-cleaner's view and representations about his job, life events and the place where they occur. It is therefore from this perceptual and conceptual point of view that the reader 'enters' the main character's referential universe and 'lives' the main narrative events. This is the dominant perspective, in which a prevalent conformist ideology is inscribed. It is introduced as follows:

The pathway cleaner worked for many years in the subway, always with the eyes on the ground. A mole, a pipe's mouse. He pricked papers with a pin at the tip of a stick and put them in a bag. He swept millions of cigarette butts ... sprinkled the railwayroads with a white and mysterious powder and every time the lantern comrade let out a shrill whistle - there comes the train! - he cowered against the black wall, in the narrow service passage where infiltration waters flowed ... All his life came from the dirty and viscous floor. (third paragraph, 68, italics added)

The first impression about the character provided to the reader from this point of view is that of a humble individual, routinely performing the tasks society does not want to do. Such is the meaning conveyed by the imperfect tense of the verbs in Portuguese.

The metaphor, 'a mole, a pipe's mouse' - undesirable animals to be eliminated - conveys the idea that the pathway-cleaner belongs to a social group that is not valued. Considering that 'metaphors tend to take dominant interests to be the interests of society as a whole' (Fairclough 1989, 120), this metaphor thus contributes to crystallising a discriminatory social representation as being normal. The social exclusion experienced by the main character is reinforced through a further metaphor, 'All his life came from the dirty and viscous floor' (68). The 'other' (Dijk 1998), with which the character is identified, is negatively presented in this narrative, thus conditioning readers' mental representation of these social groups. 
Double-voicing plays a strong role in the construction of such perspective. The use of the free indirect speech - 'there comes the train!' (68) - enhances the visualisation of the protagonist's world from the pathway-cleaner's own eyes: it transports the reader to his place of work and invites him to listen to the usual shrill whistle. Another example of the use of the free indirect speech can be found in 'This job was much better, although it was also underground. And [he] didn't have to speak English, which he hardly understood' (69), in which we listen to the worker's resigned thoughts. In this case, the option for a concessive subordination adds to the representation of the character's psychological features, as the subordinate clause contains (and thus contributes to naturalise) an assumption that jobs underground, less desirable for most people, are naturally for poor immigrants. The semantic relation between the two clauses thus allows us to understand how the character perceives his current job when compared to previous ones, conveying his resigned acceptance of something undesirable besides suggesting that there was no actual improvement, probably due to lack of initiative, agency and capacity.

Vocabulary also plays an important role in the construction of the character's point of view. Words such as 'lantern comrade' (68) strongly contribute to the construction of his social class identification; the preponderance of vocabulary loaded with negative meaning, such as in 'always eyes on the ground', 'latrines', 'black wall', 'pieces of corpses', 'bloodless bodies', 'infiltration waters', 'dirty floor' (68), enhances the dim view that the protagonist has about his restricted world, where 'ground' and 'black wall' can symbolise the obstacles and the lack of opportunities for a better life itself. However, this point of view also reveals an individual who does not question his world or his social status. The whistle and the rice were the only stimuli able to distract the worker from his daily tasks; the fact that nothing else took his eyes from the ground strengthens the mood of unresisting acceptance. And this is, indeed, the meaning that remains associated with the perspective of this character until the end of the narrative, despite the events experienced by him. The following extract corresponds to the tenth paragraph, in which the character's submissive voice is clearly audible:

\begin{abstract}
And so it was how that charitable rain of polished rice, best quality, ended giving him the real notion of Providence. That rice came from Heaven, just like the rain, the snow and the thunder. God, Above, thought about the pathway-cleaner ... and sent him that manna to fill his children's belly. Without him having asked for anything. He kept secret - it is not good to tell the prodigies with which the divine grace blesses us. He resigned himself to be the object of merciful Lord's will. And he started praying Him fervently, at night, what he had never done before: beside his wife. Rice from Heaven... (tenth paragraph, 71, italics added)
\end{abstract}

The pathway cleaner's resignation is an example of the ideology of assimilation. His attitudes (or their absence) are never judged, neither by the narrator nor by other characters, which facilitates readers' identification with this point of view, positioning themselves in accordance with a conformist ideology. This is the main significance we get by analysing the main character's point of view.

The presentation of the main character's point of view is framed by another voice, in which we identify a different perspective towards the narrated events: the narrator's perceptual and conceptual point of view, through which the narrative actually begins. The narrator focuses on the upper side of the city, guiding the readers' attention to a physically and socially divided city: 
Along the sidewalks of New York, over the subway's stations and galleries, large latticed vents open through which everything falls: the sun and the rain, the moonlight and the snow, gloves, eyeglasses and buttons, paperwork, chewing gum, women's shoe-heels that get stuck, and even money. Sometimes, deep down, in the accumulated garbage or in puddles of stagnant water, nickel or even silver coins shine. The boys kneel with their noses glued to the bars, trying to discover treasures in the obscurity... (67)

This view of the 'Uptown', given through the use of the simple present tense, suggests the host city's intransigency, materialism and indifference as an habitual state of affairs. It is through the narrator's voice that such an antipathy and disgust towards society can be heard in the first, second, fourth, fifth, sixth and eleventh paragraphs. There, it frequently intermingles with the character's point of view, as in the following example:

But the vent, if you understand me well, obliqued just like a chimney, and the grid itself became invisible from the inside. It was from there, for sure, that the rice fell, just like the coins, the dust, the rain and everything else. (seventh paragraph, 70)

In this excerpt, it is the main character's point of view that is being presented, but the expression 'if you understand me well' suggests the narrator's intention to establish a disruptive complicity with the readers. This seems to be a strategy to lead them towards a proper understanding of the narrator's point of view, in accordance with his visualisation and awareness of how the host society treats an individual from a minority group. In other moments, the same voice is particularly sarcastic towards such a non-inclusive society. In the following excerpt, the public's voice mixes with the narrator's, with an ironic and parodic effect:

Now and then there's a holy matrimony, especially when the weather is fine, or on Sundays. And such a waste of rice, I do not know where the custom comes from: perhaps a votive prediction of abundance, or a symbol of the 'Be fruitful and multiply' (like rice). One stops to look and feels like asking: 'how are you selling today's first class rice here in the parish?' (fifth paragraph, 69)

The simple present verbal tense and the caustic tone are also audible in the paragraph that closes the narrative: 'The pathway-cleaner's Heaven is the street on which other people step' (eleventh paragraph, 71).

When the narrator speaks, he does not support the character's resignation; nor does he assume the character's feelings as if they were his own. This voice is a vehicle of a liberating ideology, challenging that which is conveyed by the story and by the main character's point of view. His corrosive tone is also targeted at the dominant religious discourse (in Portugal), expressing through 'Rice from Heaven...' (71), a pre-text of 'Holy Father from Heaven...', all his disdain and profound disgust towards a religion that is compliant with social conformism and discrimination. This is the main significance we get by analysing the narrator's point of view.

\section{Pedagogical implications}

The analysis just presented supports our claim that critical reading is a fundamental dimension in the construction of empathic positions through the reading of literary narratives. It also sustains relevant pedagogical implications for the teaching of literature. In this section we discuss both. 
'Rice from Heaven' is an exemplary dialogical text, in which polyphony and double-voicing are used to create what Stephens calls an 'interrogative text' (Stephens 1992, 124), focusing on the construction of the reader's social positioning. Readers are allowed to simulate the social reality that is represented (Mar et al. 2006) and to rewrite for themselves the subjective worlds that are shown (Kidd and Castano 2013). Yet, we assume that literary knowledge and analytical thinking are needed so that readers are guided into the intended empathic reading. So the dialogue that the author initiates in the text, in which he defies and challenges socially accepted realities, needs to be perceived by the reader him or herself.

This short story seems to be a representative case of literary fiction (as opposed to popular fiction) offering readers the experience of multiple alternative perspectives (Kidd and Castano 2013). In this short story, we found tensions between opposing ideologies, which are in dispute until the very end of the text. The voice that tells the main story is a conformist one, and a superficial reading of the short story may pass the idea that assimilation of immigrants into the dominant culture is natural. The other voice, which is focused on the social circumstances that condition the main character's life, is a critical one, which, nevertheless, is very subtle and sometimes ambiguous, normally not read by young readers. However, to be able to see this ideology is to perceive a liberation possibility for the character, indeed the most consonant with the author's social activist stance.

The two opposing empathic positionings result from the ideological dialogue that is maintained throughout this story. Which of the two ideologies gains the allegiance of the reader of 'Rice from Heaven' depends on what the reader knows about reading and about the socio-cultural functioning of texts. And this will make the difference in the reader's emotional responses. We thus contend that the critical analytical framework is fundamental to develop an alternative empathic stance and may strengthen the emotional (and thus social) skills literary readers may achieve.

Some pedagogical implications can be drawn from the analysis, one concerning the relevance of the meanings constructed for student readers in migration contexts and the other the potential of the analytical procedure for teachers of literature reading.

The political circumstances that, in the 1960s, privileged the resigned meanings and hence enabled the text to be allowed in Portugal have changed profoundly; but current reality dangerously resembles that which is portrayed in the story: Portugal as a site of migratory fluxes and the political controversies about emigration from Portugal have been the issue of international news reports. ${ }^{2}$ This is no parochial concern, as this situation goes well beyond our frontiers. ${ }^{3}$ So, classrooms are now the meeting points of immigrant students and the relatives and friends of emigrants. The stance that may be explored by reading this or any other critical narrative is nowadays particularly important for legitimising social identities either in others or in student readers themselves. This is especially relevant for young (future) adults, who are likely to become emigrants themselves. In fact, we believe the subtle dialogue in which the opposing ideologies are represented in 'Rice from Heaven' is utterly realistic: in our lives, liberating ideologies intermingle with assimilatory ones, and it is the latter that offer themselves as natural.

Globalism has brought greater possibilities for young people to develop empathic feelings for the conditions of disadvantaged social groups (Rifkin 2009). We believe Stephens's critical reading literary methodology, complemented with Bakhtin's notions of dialogism, is a powerful tool to empower teachers in textual selection, 
text reading and in the design of 'critically engaging' practices (Wohlwend and Lewis 2010; Lewis and Tierney 2011) that are necessary for young readers to develop thoughtful empathic consciousnesses. Indeed, the dialogue between ideologies that students may learn to see in literary texts may be reconstructed in the students' own life experience, with a potential for allowing the experience of embodied emotions, achieving for themselves through literary textual practices a socially proactive identity, the kind of identity required by the contemporary social world (Gee 2001).

\section{Conclusion}

We conclude by reaffirming the potential of literature to enhance readers' humanity. By offering the lives of others for our contemplation, literature plays an important cultural role in the construction of mature empathic individuals. 'Rice from Heaven' is a good example of this. Critical narrative exegesis methodologies do justice to the struggles of the literary authors that have dared to deal with social issues (Alsup 2003). It empowers readers to be able to read their messages fully, develop critical empathetic meanings and to engage in social change.

Nevertheless, guiding students to experience reading literature critically to develop empathy is a demanding intellectual endeavour for teachers and students. 'Rice from Heaven' offers readers opposing but 'well-defined' perspectives about a living situation. Yet the reading of 'cruder' literary representations, in which the reader has to develop his or her empathic consciousness about what may be unsolved conflicts (Eco 1989) is an even more challenging intellectual effort for both teachers and students.

\section{Funding}

Íris Susana Pires Pereira was financially supported by Fundação para a Ciência e a Tecnologia under the project PEst-OE/CED/UI1661/2014 through Centro de Estudos em Educação at the Universidade do Minho, Portugal.

\section{Notes}

1. 'Rice from Heaven' was written in Portuguese as 'Arroz do Céu'. The italicised words are original words in English. The use of capital letters follows the original. All the translated words and excerpts, identified by inverted commas, are our responsibility.

2. See, for instance, http://www.ipsnews.net/2011/08/portugal-young-professionals-flee-cri sis-to-former-colonies/ and http://www.aljazeera.com/indepth/features/2011/12/2011123 0137979968.html.

3. See, for instance, http://www.ipsnews.net/2013/03/young-spaniards-exiled-by-unemploy ment/.

\section{Notes on contributors}

Íris Susana Pires Pereira is an Assistant Professor in the Institute of Education at the University of Minho, Portugal. She works in initial, postgraduate and in-service education of preschool, primary and upper-primary language teachers. She is a researcher at the Centre for Educational Research at the University of Minho. Her areas of research are language and literacy education as well as professional learning. 
Ângela Campos is an MA high-school teacher in the Portuguese District of Oporto, Portugal. She teaches Portuguese as mother language, and her main research interest is critical literacy education through literature.

\section{References}

Alsup, J. 2003. "Politicizing Young Adult Literature: Reading Anderson's Speak as a Critical Text." Journal of Adolescent \& Adult Literacy 47 (2): 158-166.

Bakhtin, M. 1981. The Dialogic Imagination. Austin: University of Texas Press.

Bakhtin, M. 1984. Problems of Dostoevsky's Poetics. Minneapolis: University of Minnesota Press.

Campos, A. 2012. Contributos Para O Entendimento Da Aula De Português Como Espaço De Promoção De Uma Literacia Crítica. Uma Leitura Crítica De "Arroz Do Céu”, De José Rodrigues Miguéis [Towards an Understanding of the Role of the Language Class in the Promotion of Critical Literacy. A Critical Reading of 'Rice from Heaven', by José Rodrigues Miguéis]. Tese de Mestrado em Educação não publicada. Área de Especialização em Supervisão Pedagógica em Ensino de Português [Unpublished Master Thesis on Education-Professional Development]. Braga: Instituto de Educação da Universidade do Minho.

Comber, B. 2001. "Negotiating Critical Literacies." School Talk 6 (3): 1-2.

Dijk, T. 1998. "Ideological Discourse Analysis." http://www.discourses.org/OldArticles/Ideo logical\%20discourse\%20analysis.pdf.

Dijk, T. 2001. "Critical Discourse Analysis." In The Handbook of Discourse Analysis, edited by S. Deborah, T. Deborah, and H. Hamilton, 352-371. Oxford: Blackwell.

Eco, U. 1989. The Open Work. Cambridge, MA: Harvard University Press.

Fairclough, N. 1989. Language and Power. New York: Longman.

Freire, P., and D. Macedo. 2003. "Rethinking Literacy: A Dialogue." In The Critical Pedagogy Reader, edited by A. Darder, M. Baldano, and R. Torres, 354-364. New York: Routledge.

Gee, J. P. 1996. Social Linguistics and Literacies. Ideology in Discourse. 2nd ed. London: Taylor and Francis.

Gee, J. P. 2001. "Reading as Situated Language: A Sociocognitive Perspective." Journal of Adolescent Adult Literacy 44 (8): 714-725.

Harris, W. V. 1990. "Double Voicing in Dickens and Elliot.” ELH 57 (2): 445-458.

Hollindale, P. 1988. "Ideology and the Children's Book." Signal 55: 3-22.

Kidd, D. C., and E. Castano. 2013. "Reading Literary Fiction Improves Theory of Mind." Science 342 (6156): 377-380.

Kubow, P., D. Grossman, and A. Ninomiya. 1998. "Multidimensional Citizenship: Educational Policy for the 21st Century." In Citizenship for the 21st Century: An International Perspective on Education, edited by J. J. Cogan and R. Dericott, 115-133. London: Kogan Page.

Lewis, C., and J. D. Tierney. 2011. "Mobilizing Emotion in an Urban English Classroom." Changing English: Studies in Culture and Education 18 (3): 319-329.

Luke, A., J. O'Brien, and B. Comber. 2001. "Making Community Texts Objects of Study." In Critical Literacy: A Collection of Articles from the Australian Literacy Educators', Association, edited by H. Fehring, and P. Green, 112-123. Newark, DE: IRA.

Mar, R. A., and K. Oatley. 2008. "The Function of Fiction is the Abstraction and Simulation of Social Experience." Perspectives on Psychological Science 3 (3): 173-192.

Mar, R. A., K. Oatley, J. Hirsh, J. de la Paz, and J. B. Peterson. 2006. "Bookworms versus Nerds: Exposure to Fiction versus Non-fiction, Divergent Associations with Social Ability, and the Simulation of Fictional Social Worlds." Journal of Research in Personality 40: 694-712.

Mar, R. A., K. Oatley, and J. B. Peterson. 2009. "Exploring the Link Between Reading Fiction and Empathy: Ruling out Individual Differences and Examining Outcomes." Communications 34: 407-428.

McLaren, P. 2003. "Critical Pedagogy: A Look at the Major Concepts." In The Critical Pedagogy Reader, edited by A. Darder, M. Baldano, and R. Torres, 61-83. New York: Routledge. 
Miguéis, J. R. (1962) 1990. “Arroz Do Céu [Rice from Heaven].” In Gente De Terceira Classe [Third Class People], edited by J. R. Miguéis. 5th ed. Lisboa: Editorial Estampa.

Oatley, K. 2008. “The Mind's Flight Simulator.” Eye on Fiction 21 (12): 1030-1032.

Pace, B. G. 2006. "Between Response and Interpretation: Ideological Becoming and Literary Events in Critical Readings of Literature." Journal of Adolescent \& Adult Literacy 49 (7): $548-549$.

Pereira, Í. S. P. 2009. "Literacia Crítica: Concepções Teóricas E Práticas Pedagógicas Nos Níveis Iniciais De Escolaridade [Critical Literacy: Theoretical Conceptions And Pedagogical Practices in The Initial Grades].” In Modelos E Práticas Em Literacia [Models and Practices In Literacy], edited by M. G. Sardinha and F. Azevedo, 17-34. Lisboa: Lidel.

Rifkin, J. 2009. The Empathic Civilization: The Race to Global Consciousness in a World of Crisis. Cambridge: Polity Press.

Stephens, J. 1992. Language and Ideology in Children's Fiction. London: Longman.

Volpi, J. 2011. Leer La Mente. El Cerebro Y El Arte De La Ficción [Mind Reading. The Brain and The Art of Fiction]. Madrid: Alfaguara.

Wohlwend, K. E., and C. Lewis. 2010. "Critical Literacy, Critical Engagement, Digital Technology: Convergence and Embodiment in Glocal Spheres." In The Handbook on Teaching English and Language Arts, edited by D. Lapp and D. Fisher, 3rd ed., 188-194. New York: Taylor and Francis.

Yoon, B., A. Simpson, and C. Haag. 2010. "Assimilation Ideology: Critically Examining Underlying Messages in Multicultural Literature." Journal of Adolescent \& Adult Literacy 42 (2): 109-118. 